\title{
PHYSIOLOGICAL DATA OF MICE
}

\section{BODY WEIGHT AND THE WEIGHT OF INTERNAL ORGANS OF} THE MALES OF ddD AND OFW

OKUGI Minoru, Kiyoshi SuzUkI and Yoshio TAJIMA

Institute for Infectious Diseases, University of Tokyo

Experimental animals are widely used in research work with various infectious diseases. In order to know the influence of infection upon animals, it is a useful procedure to measure the body weight and the size of internal organs. Although, it should be essential to compare the data with those obtained with normal animals, a reliable data of normal ones are not available as yet.

In this connection, the authors started to establish such a picture with normal mice. Male ddD and CF'W of from 1 to 65 days' old bred in the author's laboratory were used.

The results are as follows:

1. The periodical increase of weight of each organ was not similar. Organs of a mouse increased in weight after birth but the curves were different one another.

2. The increase of body weight and that of the weight of internal organs do not necessarily coincide.

3. In spleen, a decrease of weight was noted after certain period of time.

Further studies are being undertaken using otherstrains.

\section{CF\#1 系マウスの血球像 \\ （百日喛毒素及びワクチンによる変化）}

\begin{abstract}
武田薬品光工場細菌部 金子順一・宿田幸男・中村義治
マウスの血球像が采統によつて異り, 又白血球数が採 血部位により著しい差のあることは周知である。例えば Biology of the laboratory mouse (1956): p.93-94 には C 57 Brown, C 57 Black, BAGG, dba, C3H 采 において, 平均値として, 赤血球数 8.760-11.234 $\times 10^{6}$, 白血球数 (心血) $3,600-5,220$; 淋巴球 $63-71 \%$, 中性球 14-25\% であり，また BAGG 禾で白血球数は心血で 3,717 ; 尾静脉血で 21,510 であると記されている。Genetics of the mouse (1952) p. 251 では BA, L, E, $\mathrm{Z}, \mathrm{RI}, \mathrm{S}$ 采の各平均值として, 赤血球 6.95-9.37, 白血 球 $11.2-22.5 \times 10^{3}$; 淋巴球 $65-74 \%$, 中性球 $9-18 \%$ と, 更に大きい差を示している。

わが国で広く用いられてきた dd 禾について，石井・ 小林 (1954) は赤血球 $9.62 \times 10^{6}$, 白血球 $9.9 \times 10^{3}$; 淋 巴球 $72.8 \%$ ，中性球 $19.5 \%$ 等と報告しているが，同じ 禾統でも条件又は亜系によつて異る ののか, 長崎大学 血液病センター来賀 (1958) は ddT 系について赤血球 $10.12 \pm 1.21$, 白血球 14.90 土4.32; 淋巴球 $77.3 \pm 9.6 \%$, 中性球 $17.9 \pm 8.6 \%$ を示している。

われわれは当所の $\mathbf{C F}$ \#1 系について百日咳毒素とワ

クチンの血球像に及ぼす変化を夷験したので次に報告す る。

\section{实跧材料・方法}

マウスは当所で䇣殖している CF井1 系ㅇ生後 4 週体重 14-16 g のものを用いた。百日咳䓯素 ( 1 相桜屋敷株凍 融上清） $2.0 \times 10^{9}$ 相当量。又はマーゾニンワクチン 5.0 $\times 10^{9}$ を各 10 匹群の腹腔内に接種し，非接種対照群と ともに 1，3，6，9，15，21 日にそれぞれ尾端血につい て赤血球，白血球数を計算し，ギムザ染色標本について 的 200 簓を検して白血球分類を行つた。(ワクチン群は 8 日目に 1 匹死亡したので，9 日以後は 9 匹となつた。)

\section{成 粹}

第1 唼に示すよ5であつた。

対照群は測定日により多少の差があるが，いずれも有 意ではない。

毒素では，1 日に赤血球堌加，9１2 日に軽い貧血が みられる。白血球は 1 日に著しく増加し, 少くも 15 日 まで持稳する。中性球の比率増加る 1 日が著しく, 少く
\end{abstract}


も6 日まで続いた。

ワクチンでは 6〜9 日に軽い貧血を示すが, 白血球は 1 日から増加し 3 日に最高で 15 日まで続く。中性球増 加は 21 日まで続いているが， 6 日頃が最も著しいよう である。

対照群では, 単核球 $6.0 \pm 4.1 \%$, 好酸球 $2.5 \pm 1.1 \%$ 個体間変動も大きく，また毒・ワクチンによる変化は明 かではなかつた。

体重は，試験開始日には $15.1 \pm 0.2 \mathrm{~g}$ であつたが, 21 日後の対照群では, 途中の頻回処置のためか, $18.0 \pm 1.6$ で余り増加していない。毒素群では $17.5 \pm 2.4$ で対照と 有意差はないが，ワクチン群では $16.1 \pm 2.1$ で対照に比 して少いといえる。

これらの成績は, 毒又はワクチンの量を更に変えた奏 験を行つてからでないと, 毒・ワクチンに特有な変化を 求めるには不十分である。

\section{考按及び結論}

CF\#1 系マウス（タケダ光）の生後 4-7 週の血球像を みると，次の成績のように，大した特徴はないが，白血 球はむしろ少い系統のようである。

赤血球 $7.42 \pm 1.08 \times 10$

白血球 $7.67 \pm 1.59 \times 10$

淋巴球 $69.9 \pm 10.7 \%$

中性球 $24.3 \pm 9.6 \%$

単核球 $6.0 \pm 4.1 \%$

好酸球 $2.5 \pm 1.1 \%$

尾の採血場所によつて白血球数が異ることは動物実験 法 (1956) p. 106 にも明示されているが，われわれの実 験值は尾端を切断してえたものであつて，他の文献との 比較には常に採血部位を考慮していなければならない。 また，同じ dd でも，所により大いに異る值を示すこと からみて, この CF\#1 系の值が他のコロニーにも適用し ろるかどうかは明かではない。

百日暗毒素がマウス脾を縮少させ，ワクチンがこれを 肥大させること，及びそれが 21 日後にも持続している こと（金子，山本, 中村 : 細菌学雑誌に発表予定）から, 両者の作用を血球像の上から検討する目的で, この実験 を行つたのであるが，その結果はやや経過を異にする白 血球増多症を認め, またワクチンの方がやや持続的で且
第 1 表 OF\#1 系マウス血球像変化

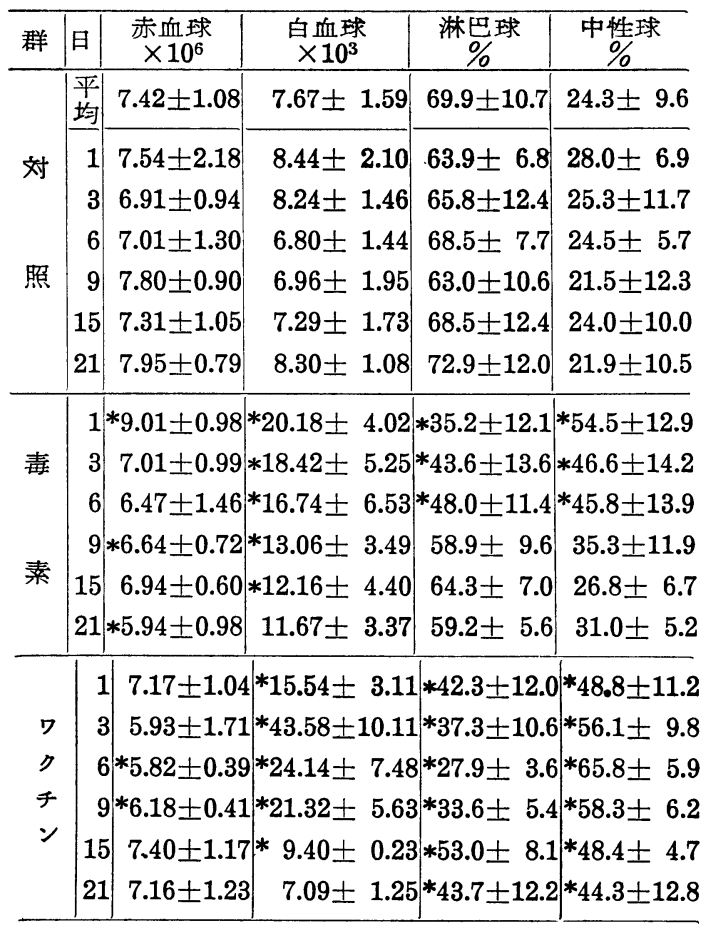

*は対照群の当日値と有意差のあるもの

高い中性球比率を示すに到ることの他には，特別な差を 認めることができなかつた。この点については，両者の 量と変動との関係を更に実験し，あるいは更に詳細な白 血球分類を行つてみなければならないと考えている。

\section{参照文献}

1. 安東洪次, 田嶋嘉雄 (1956)：動物実験法, 朝倉 書店。

2. GRÜNEBERG, H. (1952): The genetics of the mouse, Martinus Nijhoff (Netherlands).

3. 石井進, 小林和夫 (1954)： dd 系マウスと市販 マウスとの比較（特にその血液細胞所見に就て）。 実験動物彙報, 3, 13-19.

4. 糸賀 敬 (1958)：(私信)。

5. SNell, G.D. (1956): Biology of the laboratory mouse. Dover Publ., New York.

\section{BLOOD PICTURE OF THE MOUSE CF $\# 1$; CHANGES PRODUCED BY THE TOXIN AND VACCINE OF PERTUSSIS}

KaNeko Jun-ichi, Sachio ShukUtA and Yoshiharu NAKAmura Bact. Dpt., Hikari Plant, Takeda Pharm. Ind., Ltd.

Studies were made on the blood picture of mice following intraperitoneal injection of pertussis toxin and -vaccine. 
Female mice of 4 weeks' old, CF\#1 (HIKARI) were used in this experiment.

Pertussis-toxin caused marked leucocytosis on the 1st day; which gradually recovered and the normal picture was resumed in 15 days. Pertussis-vaccine also developed leucocytosis, which was most eminent on the 3rd to 6th day. The leucocytosis caused by toxin as well as vaccine was principally that of neutrophiles. The toxin caused slight erythrocytosis on the 1st day, and moderate anemia on the 9 th day. No essential difference between the toxin and the vaccine was demonstrated.

\section{マウス繁殖コロニーに於ける疾病摘発}

\section{1 サルモネラ症摘発}

\section{国立予防衛生研究所獣疫部 田中利男・新井照雄}

\section{まえがき}

マウス繁殖コロニーを維持している生産者は機会ある ごとに自己のコロニーについて検䛦を行つて, 疾病の排 除につとめるとともに, 常に健康な動物を研究公に供給 することが出来るように，コロニーを健全に保持するこ とが最も大切である。しかしながら，我国に゙扣いては繁 殖コロニーに打疾病の摘発，検診については各人の 認識も浅く従つてその具体的方法については未だ確立さ れていないのが現状である。

この場合検診の対照となるものは勿論自然感染特に不 顕性感染, 寄生虫, 遺伝的異常, 栄盖障害等広範囲に互 つているが，日本の現状よりしてわれわれは，重点を感 染病, 特に一般好気性病原細菌・エクトロメリア・HVJ の3つに置き，まず第一段階として一般好気性細菌のな
かで特にサルモネラの摘発洗について検討を試みた。未 だいろいろと検討を加えねばならない面も多いように思 われるが，一応現在までの成績をまとめてここに御報告 し，御参考に供すると共に御批判を戴きたいと思う。

\section{各生産地におけるサルモネラ検索成綡}

一応第 1 表のような方法で，まず㐨の関係している 4 地区 9 コロニーで飼育されている外観健康な生後 4 週 又は種親マウスについて検查を行つてみた。その結果, $\mathrm{A}$ 地区 2 コロニーの生後 4 週マウス 7 例 (3.18\%)より, Salmonella enteritidis が分離された（第 1 表)。し かもこれらの腸炎菌はいずれも外観健康なマウスより分 離された。

本菌によるマウスサルモネラ症の流行発生については すでに過去に数多くの報告がなされており，それらを参

第 1 表一般好気性病原細菌検查方法とその成績

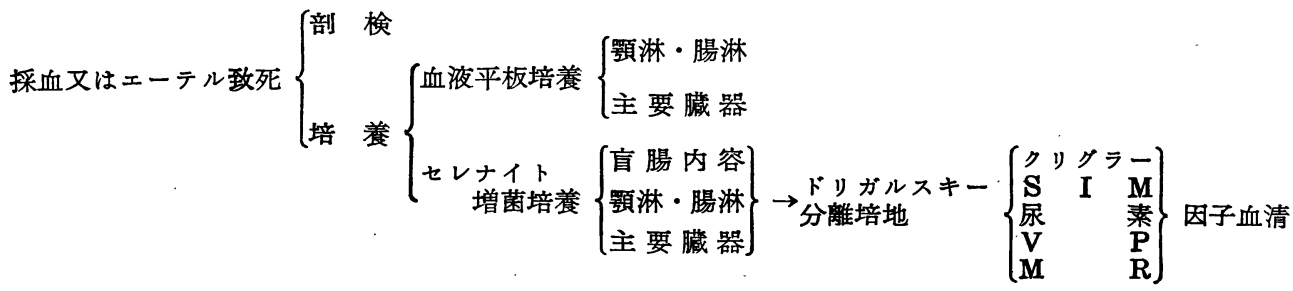

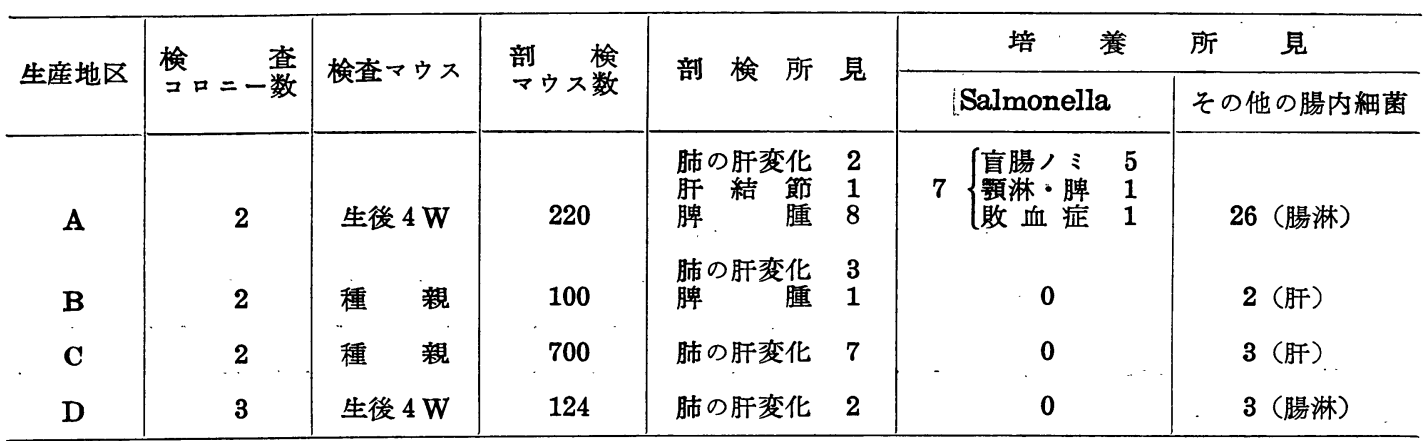

